\title{
Free education as the main idea in the preparation of a competitive graduate
}

\section{La educación gratuita como idea principal en la preparación de un graduado competitivo}

\author{
Marina N. Bulaeva \\ bulaevamarina@mail.ru \\ https://orcid.org/0000-0002-9928-9451 \\ Minin Nizhny Novgorod State Pedagogical University, Nizhny Novgorod, Russia. \\ Olga I. Vaganova \\ vaganova_o@rambler.ru \\ https://orcid.org/0000-0001-8347-484X \\ Minin Nizhny Novgorod State Pedagogical University, Nizhny Novgorod, Russia. \\ Tatiana V. Krylova \\ perova tatyana83@mail.ru \\ https://orcid.org/0000-0001-9328-9066 \\ Minin Nizhny Novgorod State Pedagogical University, Nizhny Novgorod, Russia. \\ Zhanna V. Smirnova \\ Z.v.smirnova@mininuniver.ru \\ https://orcid.org/0000-0001-9950-9824 \\ Minin Nizhny Novgorod State Pedagogical University, Nizhny Novgorod, Russia.

\section{Lyubov I. Kutepova} \\ lubovkutepova@mail.ru \\ https://orcid.org/0000-0002-3175-4978 \\ Minin Nizhny Novgorod State Pedagogical University, Nizhny Novgorod, Russia.
}

\section{Abstract}

The purpose of the article is to analyze the experience of training students in the framework of implementation the idea of free education. The study participants were students of higher educational institutions of the age group from 17 to 24 years. Throughout the study, the subjects were under the supervision of experts who recorded the features of students ' choice and the main aspects of their behavior. The study showed that students are active participants of educational process they highly appreciate the importance of free education and are ready to use its elements in teaching. The idea of implementing free education is a promising direction in the training of highly qualified specialists. 
Key Words: free education, competencies, competitiveness, professional education, professional competence.

\section{Resumen}

El propósito del artículo es analizar la experiencia de formar estudiantes en el marco de la implementación de la idea de educación gratuita. Los participantes del estudio fueron estudiantes de instituciones de educación superior del grupo de edad de 17 a 24 años. A lo largo del estudio, los sujetos estuvieron bajo la supervisión de expertos que registraron las características de la elección de los estudiantes y los principales aspectos de su comportamiento. El estudio mostró que los estudiantes son participantes activos del proceso educativo, aprecian mucho la importancia de la educación gratuita y están listos para usar sus elementos en la enseñanza. La idea de implementar la educación gratuita es una dirección prometedora en la formación de especialistas altamente calificados.

Palabras clave: educación gratuita, competencias, competitividad, formación profesional, competencia profesional.

\section{Introduction}

Paying attention to the trends of modern vocational education, higher educational institutions are looking for new ways to train specialists that will ensure their competitiveness and demand in the labor market. Today, global transformations are taking place in Russian vocational education.

One of the main ideas of modern vocational education is freedom of educational process.

Recently, the dominant idea was the existence of a system of peculiar sequential steps, courses that a student takes, adhering to the established program. It is difficult to overestimate the advantages of this system, since the designer of educational program clearly represents what a student should know and be able to do. In the conditions of the planned distribution (job providing) of higher educational institutions graduates with jobs, which was typical of the Soviet educational space, this system allowed achieving high results. The requests of labor rank were fully satisfied, since higher educational institutions knew the requests for specialists, for their specific number and profile. It was quite easy to predict who they would work with, in a few years' time and for what enterprises.

It should be noted that the dynamics of innovative technologies development was much slower than today, so the implementation of the main professional educational program without changes could take place for a long time and quite effectively. 
This model remains relevant and effective in certain areas of training to date, but due to the changing demands of society, there is a need for its transformation. Technical progress is gaining high rates, technologies are developing.

For a modern person, a frequent change of work place is spread. In these conditions, it becomes impossible to prepare a specialist for a certain field of activity where he will be employed for many years.

People change not only their work place, but also their profession (Shashlo et al., 2018). There is a need to prepare both for a specific type of activity, and to form the student's ability for professional self-improvement and rapid adaptation to a new professional activity (Smirnova et al., 2020).

Ensuring educational process freedom becomes a significant factor in development of future graduates competitiveness. The concept of freedom includes many elements (Kiseleva et al., 2019). This should include individualization, informatization, technologization, continuity, and other factors.

The student is placed in the position of educational process participant who actively and creatively solves educational problems, is included in various projects, competitions of professional skills (Tezer et al., 2019). The educational process is based on the terms of partnership (Vaganova et al., 2019). The teacher becomes a consultant of the learning process (Tsarapkina et al., 2021).

Modern training strives to ensure that the student has the opportunity to freely and independently choose the courses that he needs (Aniskin et al., 2020).

The idea of lifelong learning which was established several years ago in Russian education, allows us to complement and form the missing competencies in this way (Dobudko et al., 2019). The concept of designing a personal educational route becomes significant.

For the further formation of competitive specialists in modern conditions, who are ready to quickly navigate in rapidly changing conditions, monitoring of educational process is required.

\section{Theoretical framework}

Today, free education formats are being developed that implement the idea of liberal arts and sciences that contribute to the development of meaningful interaction between the student and educational program developers (Vaganova et al., 2020). Along with the idea of free education, the idea of introducing a free curriculum is developing. It exists in pilot projects of several professional educational institutions (Kharytonov et al., 2019). Their task is to provide students with a certain amount of freedom, having previously structured 
the process to prevent possible disorientation of students when they build an individual learning route (Pichugina \& Bondarchuk, 2019).

The task of free training is to give a lot of soft skills, to provide understanding of one or more disciplinary areas so that a graduate can work in a free market where there are no strict training requirements or go further to study (master's, postgraduate studies) (Mazanyuk et al., 2020).

The tasks of implementing free education include:

- preparation for a comfortable life in the information society (Demidov et al., 2020);

- improving the quality and effectiveness of the educational process at all levels of the education system.

Today there are projects in Russia that are aimed at free education development, including school education. It is worth mentioning the project "School 800", which implies a step-by-step individualization of education, starting from the second stage (high school) (Kidina, 2020). The school will implement more than ten training areas. Students will be able to choose the most suitable among them (Yarygin et al., 2019). Such a system of early career guidance will allow retaining highly qualified specialists in the region (Pinkovetskaia et al., 2020).

The principles on which free learning is based in general and the individual educational route separately include: reliance on subjective experience (Shcerbakova \& Shcerbakova, 2019); orientation to self-development and self-improvement (Vaganova et al., 2019); development of communication skills, critical thinking (Bulaeva, et al., 2018), (Nagovitsyn et al., 2020); individual pace of learning (Ivanova \& Korostelev, 2019); individual format of information presentation (Nagovitsyn et al., 2020).

Free learning and individualization also involve visualization of information, process control and feedback.

\section{Methodology}

The study was conducted in 2019-2020. The participants were students of higher educational institutions aged 17 to 24 years. Six groups of students were asked to develop their own learning trajectory without relying on the existing program and their chosen direction of study. They were asked to choose a different direction and profile and choose disciplines and courses for themselves, as well as the sequence of their study.

Throughout the study, the subjects were under the supervision of experts, who recorded peculiarities of the students' choice and the main aspects of their behavior. They were asked to take part in several surveys. Students needed to agree with the statement or refute it. A certain number of points is provided for each answer. On a scale of 1 to 4 , 
students expressed their degree of agreement. 1 - strongly disagree, 2 - rather disagree, 3 - rather agree than disagree, 4 strongly agree.

\section{Results and discussion}

As part of educational process in higher educational institutions, a study was conducted among students (from the first to the fourth year). Students were invited to participate in construction of their own individual educational route without reference to the existing program. The students were able to choose the necessary disciplines and additional courses, in their opinion.

Despite the fact that each student had the opportunity to individually and independently choose disciplines and courses, the observation showed that during the process of study many students preferred to unite. Joining groups made it easier for students to cope with the choice, since everyone was able to offer arguments in favor of a particular course.

To obtain the results of the study, a survey was conducted among the subjects on the topic of free education which included 35 statements. The article presents some of them: "I believe that free education is the key to a successful professional future of a modern specialist", "Free education expands the possibilities of my training", "I am able to independently choose necessary courses, this does not cause me difficulties", "I am completely ready for transition to free education", "I like the idea of free education", "I had difficulties with research process", "I believe that a complete transition to free education contributes to improving the quality of student training", etc.

The task of the students was to agree or refute the statement on a scale from 1 to 4 , where 1-does not agree with the statement, 4-completely agrees.

The results of the survey are presented in the table.

Table 1.

Results of a survey of students on the implementation of free education.

\begin{tabular}{lc}
\hline \multicolumn{1}{c}{ Statement } & Answer \\
\hline $\begin{array}{l}\text { "I believe that free education is the key to } \\
\text { a successful professional future modern } \\
\text { specialist" }\end{array}$ & 3 \\
\hline $\begin{array}{l}\text { "Free education expands my training } \\
\text { opportunities" }\end{array}$ & 3 \\
\hline $\begin{array}{l}\text { I believe that today it is necessary to } \\
\text { introduce elements of free education }\end{array}$ & 4 \\
\hline "I am able to independently choose the \\
necessary courses, this does not cause \\
me any difficulties"
\end{tabular}


"I am fully prepared for the transition to 1 free education"

"I love the idea of free education"

"During the research I had difficulties" 4

"I believe that a complete transition to free education contributes to the improvement of the quality of student preparation"

The results showed that students are not ready for transition to free education. They face difficulties during the selection of courses and many doubt the accuracy of their choice. But they actively accept the elements of free education, which provide an opportunity for creativity and professional self-improvement under the guidance of a teacher. Students as active subjects of the educational process show the best results of training.

To determine the principles by which students chose certain programs, the following survey was conducted among the respondents, which included 25 variants of statements, the evaluation of which was carried out according to the previous scheme, in which 1 disagree, 4 - completely agree.

A fragment of the statements is presented in the table.

Table 2.

Revealing the reasons for the selection of certain courses by students.

\begin{tabular}{|c|c|}
\hline Statement & Answer \\
\hline $\begin{array}{l}\text { "I didn't have a plan for the selection of } \\
\text { courses." }\end{array}$ & 4 \\
\hline $\begin{array}{l}\text { "Choosing courses, I was based on my } \\
\text { own interests" }\end{array}$ & 3 \\
\hline $\begin{array}{l}\text { "I chose those courses, the schedule of } \\
\text { which I liked the most" }\end{array}$ & 3 \\
\hline $\begin{array}{l}\text { "I think these disciplines are the easiest to } \\
\text { learn." }\end{array}$ & 3 \\
\hline $\begin{array}{l}\text { "I have an idea about this professional } \\
\text { area, it was not difficult for me to find the } \\
\text { necessary courses" }\end{array}$ & 4 \\
\hline $\begin{array}{l}\text { "I am equally interested in discipline and } \\
\text { technical and humanitarian cycle" }\end{array}$ & 4 \\
\hline $\begin{array}{l}\text { "I consider the disciplines of both } \\
\text { technical and humanitarian } \\
\text { cycle equally important for my education" }\end{array}$ & 4 \\
\hline $\begin{array}{l}\text { "I choose the disciplines and courses that } \\
\text { I know best" }\end{array}$ & 3 \\
\hline
\end{tabular}


According to the results of the survey, several groups of reasons for choosing were identified: 1-personal interest; 2 - a clear idea of professional activity; 3 - importance for the student of technical and humanitarian areas - (everything should be in balance), 4-avoidance of complex subjects - the student does not want to study any sciences (depending on his inclinations and predispositions). These groups were formed based on the results of the most common responses.

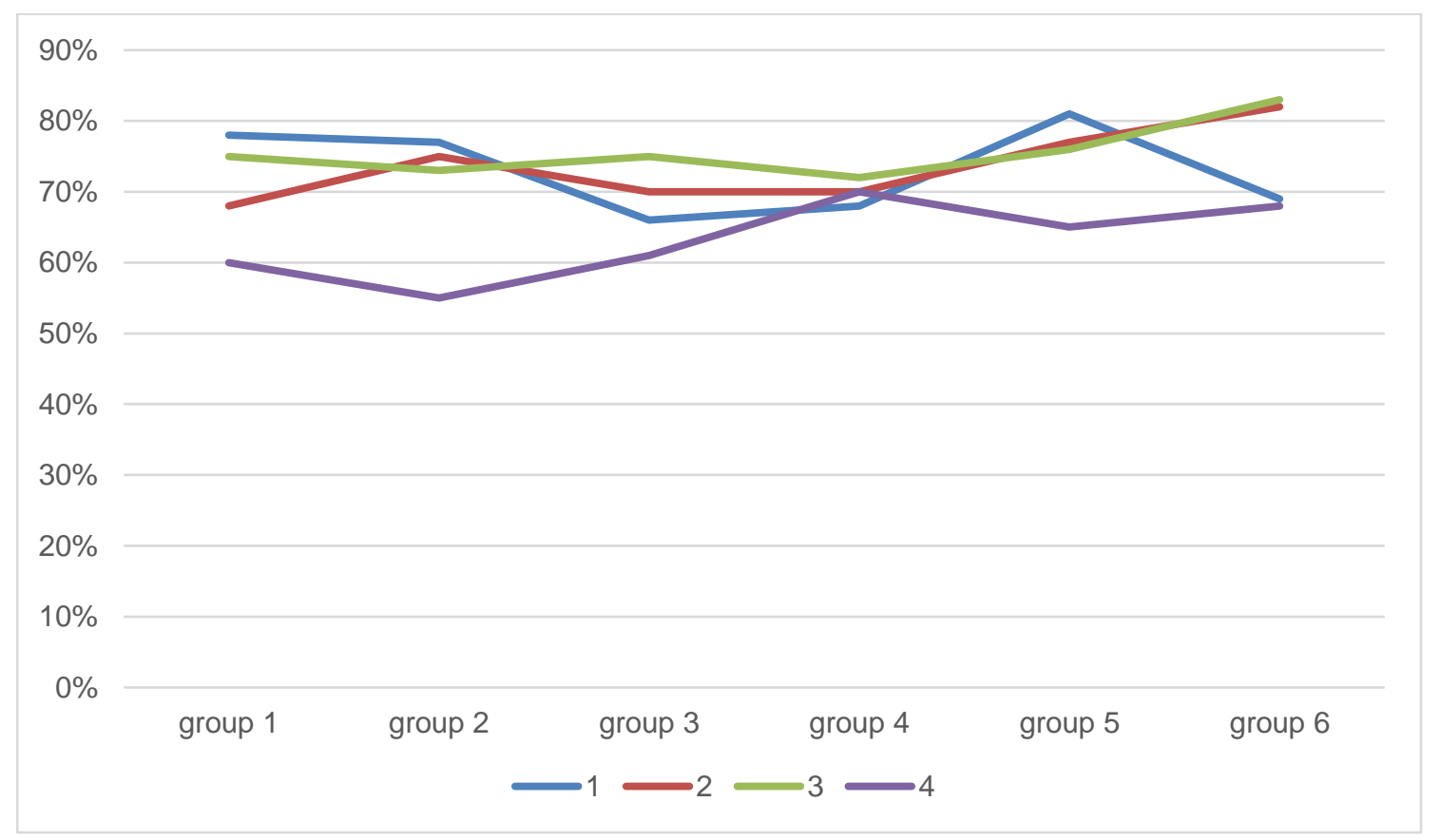

Fig. 1. Choice distribution of specific courses and disciplines by students.

Junior students most often rely on their own interests. The older the course, the more formed the ideas about professional activity are and the grounds for selecting a course change. In most cases, students still do not have a clear action plan for selecting a course and are mostly guided by their interests and assumptions. Although several groups were identified that thoroughly approached the choice of courses and disciplines and are ready to study them independently.

In the course of the study, the students noted exactly what skills they were able to improve in the process of participating in the study. 


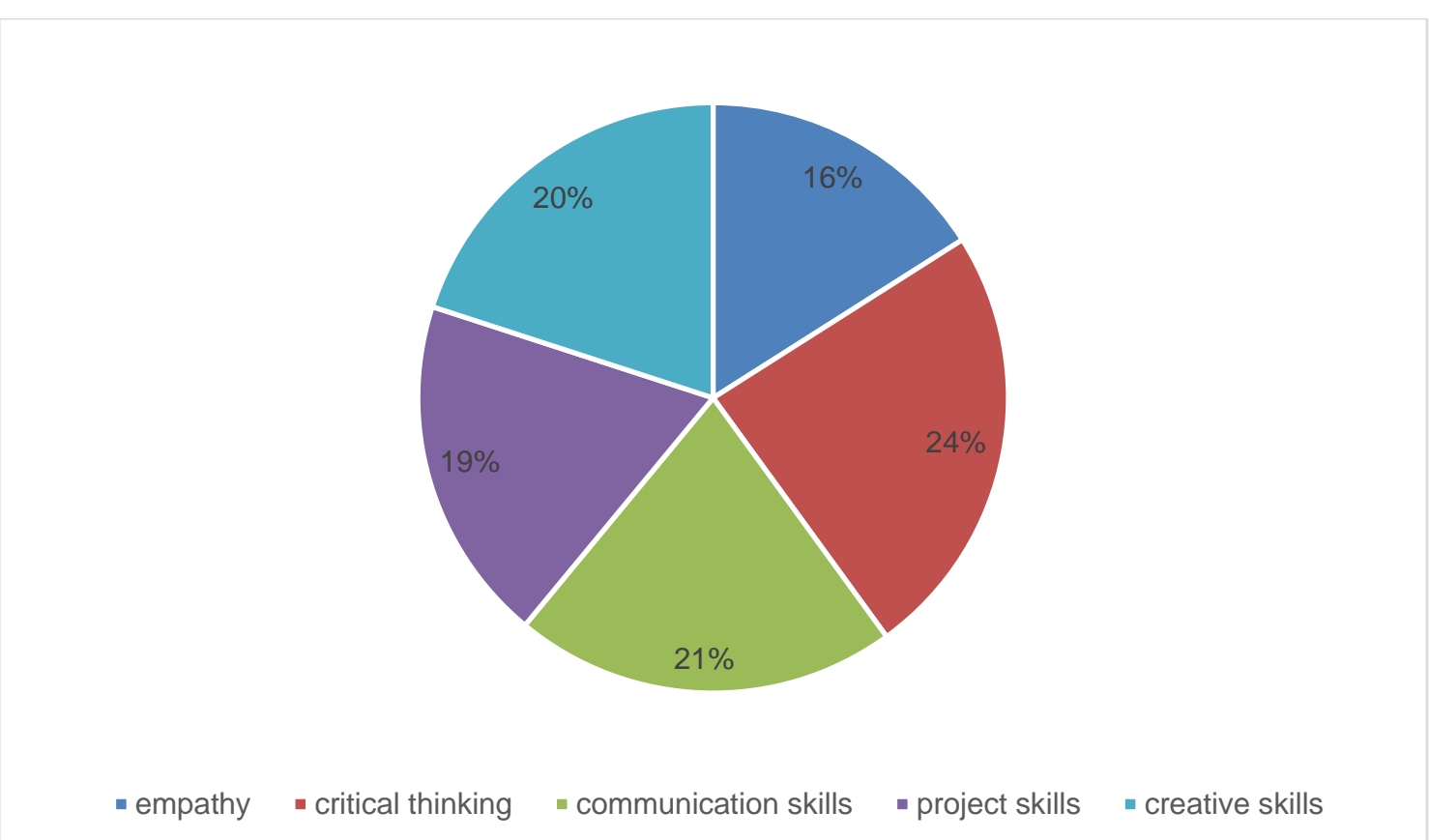

Fig. 2. Improving skills in the process of implementing free learning.

Soft skills that the students noted are an important component of modern training, important to develop a competent specialist. Students identified the ability to communicate, project skills, empathy, critical thinking, and a creative approach among the main ones.

We can say that the idea of free education can be successfully implemented in the future. Most students are ready for a gradual and systematic transition to free education. Currently available educational tools provide ample opportunities for individualization of the educational process and creative professional self-realization of students.

\section{Conclusions}

Ensuring the individualization of the educational process and the freedom of the student become an integral part of the training of highly qualified specialists who are ready to carry out professional activities at a high level and creative adaptation to rapidly changing conditions.

The number of projects implemented by educational institutions aimed at ensuring the freedom of educational choice is increasing.

The study showed that students are active participants of educational process. They highly appreciate the importance of free education and are ready to use its elements in teaching. 
Marina N. Bulaeva, Olga I. Vaganova, Tatiana V. Krylova, Zhanna V. Smirnova, Lyubov I. Kutepova.

A modern student not only has the competencies necessary for implementation of a specific professional activity, but also the ability to constantly improve professionally. Modern students form a systematic vision of their learning, the competent construction of an educational route.

\section{Bibliographic references}

Aniskin, V. N., Korostelev, A. A., Lvovna, B. A., Kurochkin, A. V., \& Sobakina, T. G. (2020). Teaching potential of integrated learning technologies Smart, Stem and Steam. Revista De La Universidad Del Zulia, 11(29), 328-336.

Bulaeva, M. N., Vaganova, O. I., Koldina, M. I., Lapshova, A. V., \& Khizhnyi, A.V. (2018). Preparation of Bachelors of Professional Training Using MOODLE. Advances in intelligent systems and computing, 622, pp. 406-411.

Dobudko, T.V., Korostelev, A.A., Gorbatov, S.V., Kurochkin, A.V., \& Akhmetov, L.G. (2019). The organization of the university educational process in terms of digitalization of education. Humanities and Social Sciences Reviews. 7(4), pp. 1148-1154.

Demidov, A., Syrina, T., \& Tretyakov, A. (2020). Development of Digital Skills and Media Education System: From the Organization of Environmental Education of Preschool Children to the ICT Competence of Teachers. Media Education (Mediaobrazovanie), 1, pp. 11-23. http://ejournal53.com/journals_n/1584456608.pdf

Ivanova, N., \& Korostelev, A. (2019). The impact of competitive approach on students' motivation in sport. Amazonia Investiga, 8(18), 483-490. Retrieved from https://amazoniainvestiga.info/index.php/amazonia/article/view/362

Kidina, I. M. (2020). Management of the pedagogical collective in the conditions of implementing distance learning. Baltic Humanitarian Journal. (Baltic Humanitarian Journal), Vol. 9 No 4 (33), pp. 93-96.

Kharytonov, E., Kharytonova, O., Tolmachevska, Y., Fasii, B., \& Tkalych, M. (2019). Information Security and Means of Its Legal Support. Amazonia Investiga, 8(19), 255-265. Retrieved from https://amazoniainvestiga.info/index.php/amazonia/article/view/227

Kiseleva, O., Lebedev, A., Pinkovetskaia, I., Rojas-Bahamón, M., \& Arbeláez Campillo, D. (2019). Specialization and concentration of small and medium enterprises employees: Russian data. Amazonia Investiga, 8(20), 6-15. Retrieved from https://amazoniainvestiga.info/index.php/amazonia/article/view/59

Mazanyuk, E.F., Tretyakov, A.L., \& Amichba, L.R. (2020). Game technologies as a tool of motivation and improvement the quality of university students' training. SHS Web of Conferences: International Scientific and Practical Conference «Teacher Professionalism: Psychological and Pedagogical Support of a Successful Career» (ICTP 2020), Yalta, Russia, October 21-23, 2020. Vol. 87. 00108. https://www.shsconferences.org/articles/shsconf/abs/2020/15/shsconf_ictp2020_00108/shsconf_ictp 2020_00108.html

Nagovitsyn, R. S., Vaganova, O. I., Kutepov, M. M., M. L. N., Kosenovich, O. V, Moeseev, Yu. V., Vorotova, M. S., \& Osipov, A. Y. (2020). Interactive Technologies in Developing Student's Motivation in Physical Education and Sport. International Journal of Applied Exercise Physiology, 9(6), 78-85. 
Pichugina, G.A., \& Bondarchuk, A.I. (2019). Structure of the training case in the organization of the educational process. Humanitarian Balkan Research, 2(4), pp. 5-7.

Pinkovetskaia, I., Berezina, N., \& Sverdlikova, E. (2020). The main reasons for the exit of entrepreneurs from business. Amazonia Investiga, 9(26), 68-73. https://doi.org/10.34069/Al/2020.26.02.7

Pinkovetskaia, I., Kryukova, L., Arbeláez, D., \& Rojas-Bahamon, M. (2019). Female Entrepreneurship: Types of Economic. Activity. Tarih kultur ve sanat arastirmalari dergisi-journal of history culture and art research, 8(2), 253-265. DOI: 10.7596/taksad.v8i2.2153

Shashlo, N., Petruk, G., \& Korostelev, A. (2018). Determinants of integration interaction among the subjects of the entrepreneurial innovation ecosystem of macro region. Amazonia Investiga, 7(13), 351-363. Retrieved from https://amazoniainvestiga.info/index.php/amazonia/article/view/569

Smirnova, Z.V., Vezetiu, E.V., Vaganova, O.I., Pluzhnikova, E.A., \& Akimova, I.V. (2020). Automated knowledge management through e-testing. International Journal of Advanced Trends in Computer Science and Engineering, 9(3), pp. 3256-3260.

Shcerbakova, E.V., \& Shcerbakova, T. N. (2019). Experience of Use of Remote Computer Technologies at The Organization of Independent Work of Students in The Conditions of a Mark and rating system. Baltic Humanitarian Journal. (Baltic Humanitarian Journal), Vol. 8, No 4 (29), pp. 192-195.

Tsarapkina, J. M., Plahina, L. N., Konoplyuk, N. V., Vaganova, O. I., \& Lapshova, A. V. (2021). The formation of bachelors' digital competencies at the university. Propositos $y$ representaciones, 9, № SI, Article number e811.

Tezer, M., Yildiz, E.P., Masalimova, A.R., Fatkhutdinova, A.M., Zheltukhina, M.R., \& Khairullina, E.R. (2019). Trends of augmented reality applications and research throughout the world: meta-analysis of theses, articles and papers between 2001-2019 years. International Journal of Emerging Technologies in Learning, T. 14, № 22, pp. 154-174.

Vaganova, O.I., Korostelev, A.A., Smirnova, Z.V., Abramova, N.S., \& Dolmatov, S.N. (2019). Improving teachers' professionalism through the development of creativity. International Journal of Innovative Technology and Exploring Engineering, 8(8), pp. 630-634.

Vaganova, O. I., Petrozitskaya, I. A., Snatovich, A. B., Odarich, I. N., \& Kirillova, I. K. (2020). Heuristic technologies of training in professional education. Amazonia Investiga, 9(27), 509-517. https://doi.org/10.34069/Al/2020.27.03.55

Yarygin, O.N., Korostelev, A.A., Akhmetov, L.G., \& Maseleno, A. (2019). Modeling of competence as a tool of goal setting for education in modern society. International Journal of Recent Technology and Engineering, 7(6), pp. 72-77. 